\title{
Anti-Shia mass mobilization in Indonesia's democracy: godly alliance, militant groups and the politics of exclusion
}

\author{
M. Khusna Amal \\ State Institute for Islamic Studies (IAIN) Jember \\ E-mail:iza_jbr@yahoo.com
}

DOI: $10.18326 /$ ijims.v10i1.25-48

\begin{abstract}
This article examines violence against religious minorities, especially Shia groups in the democracy of Indonesia, focusing particularly on the case of the 2016 antiMilad Fatimah (Fatimah Birth Commemoration) mass mobilization performed by IJABI (The all-Indonesia Assembly of Ahlul Bait Associations) in Bondowoso, East Java, Indonesia. This article finds that the anti-Milad Fatimah mass mobilization involved alliances and conspiracy between Godly Muslim groups with a varied agenda. Sunni militant groups from the Nahdlatul Ulama (NU), FPI (Islamic Defenders Front), Wahabi/Salafi, and Hizbut Tahrir Indonesia (HTI) groups, which merged into FOKUS (Ahlus Sunnah Wal Jama'ah Communication Forum), were the main protagonists who played a key role in driving mass mobilization. Unlike previous studies that understood the anti-Shia movement merely as a form of affirming Islamic orthodoxy, this study finds evidence that there were wider agendas than the theological ones. Excluding the Shia from capturing Islamic public space and challenging religious authority and local power which was dominated by moderate Muslim groups were the socio-political agendas which
\end{abstract}


contributed to the anti-Milad Fatimah mass mobilization. The involvement of radical Islamist groups, such as the activists of the Tarbiyah and HTI heralded a strong political agenda behind mass mobilization. However, the ultimate goal of applying Islamic Sharia will never fade from the religious movements of Islamist groups.

Studi ini mengkaji kekerasan terhadap minoritas agama khususnya kelompok Shia di Indonesia era demokrasi. Tulisan memilih kasus aksi mobilisasi massa anti-Milad Fatimah yang dilaksanakan oleh IJABI (Ikatan Jama'ah Ahlul Bait Indonesia), Bondowoso, Jawa Timur pada 2016. Tulisan ini memeroleh temuan yang menarik bahwa aksi mobilisasi massa anti-Milad Fatimah, melibatkan aliansi longgar di antara kelompok-kelompok Godly Muslim dengan agendanya yang tidak tunggal. Kelompok-kelompok militant Sunni dari kalangan NU, FPI, Wahabi/Salafi dan HTI, yang menggabungkan diri ke dalam FOKUS (Forum Komunikasi Ahlus Sunnah wal Jama'ah), merupakan aktor-aktor utama yang berperan penting dalam memobilisir aksi massa tersebut. Berbeda dari kajiankajian yang umumnya memahami gerakan anti-Shi' ah sebagai bentuk peneguhan ortodoksi Islam atupun homogenisasi Islam Indonesia, studi ini mendapati temuan yang jauh lebih besar dan kompleks dari sekedar agenda teologis itu. Mengekslusi Shi' ah dari ruang public Islam dan menantang otoritas keagamaan dan kekuasaan local yang didominasi oleh kelompok-kelompok Muslim moderat merupakan sejumlah agenda sosio-politik yang turut mewarnai aksi massa itu. Keterlibatan kelompok-kelompok Islamisme radikal seperti aktivis Gerakan Tarbiyah dan Hizbut Tahrir Indonesia (HTI), menjadi sinyalemen cukup kuat adanya agenda politis di balik aksi massa. Bagaimanapun, imaginasi dan citacita penerapan syari'at Islam tidak akan pernah pudar dari gerakan keagamaan kelompok-kelompok Islamis.

Keywords: Sunni, Shia Mass Mobilization, Religious Militants, and Democratization

\section{Introduction}

After the 1998 reformation, the year of the fall of Suharto's authoritarian regime and the rise of radical groups, whose ideal was to apply sharia 
comprehensively, ${ }^{1}$ frequent occurrences of religious violence continued. The trend tends to increase year on year rather than decrease, as can be seen from the reports of various Non-Government Organizations (NGOs). The Setara Institute for Democracy and Peace, for example, reports an increasing number of violent incidents, with 135 cases in 2007, 265 cases in 2008, 200 cases in 2009, 216 cases in 2010, 244 cases in 2011, and 264 cases in 2012. ${ }^{2}$ The latest figures presented by Komnas HAM reported 74 cases in 2014, increasing to 78 cases in 2015, and reaching nearly 100 cases in $2016 .^{3}$

Amidst this religious violence, minority groups, and particularly the Shia, remain the main target. ${ }^{4}$ The Shia are not merely stigmatized as a heretical and deviant group, but also suffer differing forms of violence such as discrimination, persecution, mistreatment, destruction of places of worship, and exclusion, ${ }^{5}$ in a number of geographical areas, including Batang (Central Java) in 2000 and 2006, Bondowoso and Bangil (East Java) in 2007, Sampang (Madura, East Java) in 2011, Jember (East Java) in 2012,

\footnotetext{
${ }^{1}$ Robert W. Hefner, "Religious Resurgence in Contemporary Asia: Southeast Asian Perspectives on Capitalism, State, and the New Piety", The Journal of Asian Studies, Vol. 69, No. 4 (2010), 1031-47; Noorhaidi Hasan, Islamizing Education: Integrated Islamic School and New Trend Formal Education Institution in Indonesia, SS. Rajaratnam School of International Studies, 2009: 1; Sumanto Al-Qurtuby, "Arab and 'Indo-Arabs' in Indonesia: Historical Dynamics, Social Relations and Contemporary Changes", International Journal of Asia Pacific Studies, Vol. 13, No, 2 (2017), 45-72.

${ }^{2}$ Kees van Dijk and Nico J.G. Kaptein (ed.), Islam, Politics and Change, the Indonesian Experience after the Fall of Suharto, Leiden University Press, 2016: 14; Setara Institute, Negara Harus Bersikap: Tiga Tahun Laporan Kondisi Kebebasan Beragama/Berkeyakinan di Indonesia, Jakarta: Setara Institute, 2010.

${ }^{3}$ Kompas, 5 Januari 2017.

${ }^{4}$ Chiara Formichi, "From Fluit Identities to Sectarian Labels, a Historical Investigation of Indonesia's Shi'i Communities”, Al-Jami'ah: Journal of Islamic Studies, Vol. 52, No. 1 (2014), 101-126.

${ }^{5}$ Setara Institute, Negara Harus Bersikap: Tiga Tahun Laporan Kondisi Kebebasan Beragama/ Berkeyakinan di Indonesia, Jakarta: Setara Institute, 2010; Wahid Institute, Laporan Kebebasan Beragama/Berkeyakinan dan Toleransi, 2010, Jakarta: Wahid Institute.
} 
Yogyakarta in 2013. ${ }^{6}$ Based on these cases, it can be said that the rise of frequent violence against the Shia in particular, and minority communities in general, has been part of the national trend in the post-New Order era.

The emergence of violent actions against the Shia is closely related to an ideological contest, particularly between the Ahlus Sunnah wal Jama'ah (Sunni) groups versus non-Sunni groups such as the Shia. As representatives of mainstream Islam, Sunni Muslims have an interest in maintaining their religious authority and orthodoxy. ${ }^{7}$ It must be acknowledged that this ideological contest contributes to encouraging the various violent actions of a religious nature performed by conservative and radical Sunni against the Shia minority. In the name of Islam, they often justify their actions as a manifestation of a holy struggle in establishing authentic Islamic teaching. ${ }^{8}$ In a number of violent tragedies suffered by Shia groups, as outlined above, it is clear that religion plays a significant part in inciting hatred and suspicion, encouraging misunderstanding, and provoking conflict accompanied by violence. ${ }^{9}$

However, attempting to explain violent actions against the Shia minority merely in terms of a contest on the ideological spectrum, which culminates

${ }^{6}$ Fauziah, "Potret Kerukunan Hidup Umat Beragama di Kabupaten Bondowoso, Jawa Timur", Harmoni Jurnal Multikultural EB Multireligius, Vol. X, No. 3 (2011), 647-661; Masdar Hilmy, "The Political Economy Sunni-Shi'ah Conflict in Sampang Madura”, Al-Jami'ah: Journal of Islamic Studies, Vol. 53, No. 1 (2015), 27-57; Chiara Formichi, "From Fluit Identities"..., 101-126; Al-Makin, "Homsogenizing Indonesian Islam: Persecution of the Shia Group in Yogyakarta”, Studia Islamika Vol. 24, No. 1 (2017), 1-31; Wahyudi Akmaliah, "Kekerasan dan Pengusiran Atas Nama Agama Pasca Rejim Orde Baru: Studi Kasus Konflik Syi’ah Sampang”, Maarif: Arus Pemikiran Islam dan Sosial, Vol. 10, No. 2 (2015), 221-242.

${ }^{7}$ Chiara Formichi, "From Fluit Identities", 101-126; Al-Makin, "Homogenizing Indonesian Islam”, 1-31; Ken Miichi, Minority Shi'a Groups as a Part of Civil Society in Indonesia, 2016, http:// www.mei.edu/content/map/minority-shi-groups-civil-society-indonesia?print; Syamsul Rijal, "Internal Dynamics within Hadrami Arabs in Indonesia From Social Hierarchy to Islamic Doctrins", Journal of Indonesian Islam, Vol. 11, No. 1 (2017), 1-28.

${ }^{8}$ Kees van Dijk and Nico J.G. Kaptein (ed.), Islam, Politics and Change, the Indonesian Experience after the Fall of Suharto, Leiden: Leiden University Press, 2016, 13.

${ }^{9}$ Haryatmoko, Dominasi Penuh Muslihat Akar Kekerasan dan Diskriminasi, Jakarta: Gramedia, 2010, 82-83. 
in Islamic orthodoxy will certainly not give a comprehensive understanding of the issues. Such analysis tends to ignore the socio-political interests of those who claim to be defenders of Islam, for the anti-Shia groups often involved in violent actions in the name of Islamic authenticity are not one homogenous entity. The Indonesian Council of Ulama (MUI), Indonesian Council of Young Intellects and Ulama (MIUMI), Anti-Shia National Alliance (ANNAS), Wahabi/Salafi, conservative Nahdlatul Ulama (NU), and Muhammadiyah are all known as orthodox Muslim groups, but the forms of religious orthodoxy for which they struggle will certainly never be identical. Perhaps they all imagine an Indonesia without Shia, but they do not all desire Indonesia to be an Islamic state in the same way as do radical Islamic groups such as HTI. ${ }^{10}$

This paper intends to analyze the new trend of violent actions against religious minorities, particularly Shia, which practically involves coalition and conspiracy between intolerant groups in the Indonesian democratic era. This paper argues that, behind the anti-Shia mass mobilization sponsored by both conservative and radical Sunni groups, there are more significant and more varied agenda than merely the affirmation of Islamic orthodoxy in Indonesia. By taking the case of the 2016 anti-Milad Fatimah mass mobilization in Bondowoso, it is revealed that the collective action involves a form of a loose coalition between the conservative NU, FPI, and Salafism/Wahabism among the followers of the Al-Irsyad, PKS activists, and HTI. Their joint interest in rejecting Milad Fatimah is the factor bringing them together to establish a coalition. This paper also discovers

${ }^{10}$ Endang Turmudi dan Riza Sihbudi (ed.), Islam dan Radikalisme di Indonesia, Jakarta: LIPI, 2005, 120-153; Abdurrahman Wahid (ed.), Ilusi Negara Islam: Ekspansi Gerakan Islam Transnasional di Indonesia, Jakarta: Gerakan Bhinneka Tunggal Ika, the Wahid Institute dan Maarif Institute, 2009, 130; Masdar Hilmy, "The Politics of Realitation: The Backlash of Radical Islamists to Deradicalization Project in Indonesia”, Al-Jami'ah, Vol. 51, No. 1 (2013), 129-158. 
that, behind the rejection of Milad Fatimah, there are hidden ideological and political agenda, specifically Islamizing public space and fighting for religious authority and local power.

\section{Shia in Bondowoso}

Bondowoso is a regency in the eastern part of the province of East Java, with a relatively large Shia community: according to Habib Baqir, the chairman of IJABI Bondowoso, the number of Shia followers in this region is estimated to be up to 10,000 people. This number excludes people classified as devotees of ahlul bait (people of the House of the prophet), those who follow the religious traditions and rituals practiced by the sayyid (literally "master") or habib (beloved) but do not expressly claim to be followers of Shia. In the view of NU elites, when the criteria include Muslims classified as devotees of ahlul bait, the number will be quite considerable, since the majority of $\mathrm{NU}$ followers are adherents of ahlul bait, who are considered to be direct descendants (dzurriyah) of Prophet Muhammad.11

Historically, the development of Shia communities in Bondowoso cannot be separated from the introduction and development of Islam in the archipelago through the early Islamic missionaries from Gujarat, Persia, Arabia, etc. ${ }^{12}$ In Bondowoso, the early Islamic missionaries are derived from Hadramaut-Arabs who came to some regions in the archipelago in the eighteenth century. ${ }^{13}$ One of the earliest Hadramaut Ulamas to spread Islam in the Bondowoso area was al-Habib Muhammad bin Ahmad al-

\footnotetext{
${ }^{11}$ Interviews with Habib Baqir, 25 November 2017; Habib Murtadlo, 25 November 2017; Syarifah Nawirah and Syarifah Nawiyah, 5 Desember 2017; Habib Umar, 8 September 2017; and K.H. Abd Qodir Syams, 18 November 2017.

${ }^{12}$ Moh Hasim, "Syi' ah: Sejarah Timbul dan Perkembangannya di Indonesia”, Jurnal Analisa, Vol. 19, No. 02 (2012), 147-158.

${ }^{13}$ Sumanto Al-Qurtuby, Arab and 'Indo-Arabs' in Indonesia”..., 45-72.
} 
Muhdhor (1863-1926 M). ${ }^{14}$ With the migration of Arabs to Bondowoso, a village later known as the 'Arab village' was established, and, indeed, Arab city fortresses were built in the 1880s in a number of areas in East and Central Java, including Bondowoso. ${ }^{15}$

Meanwhile, the polarization and tension between Sunni and Shia started in the 1980s when Habib Hamzah bin Ali al-Habsy, known for his religious knowledge, charisma, and position as the teacher of habaib and traditionalist Muslims in Bondowoso, declared himself a Shia follower. There is an extensive body of knowledge explaining that Habib Hamzah became a Shia follower during the Iranian revolution initiated by Imam Khomeini in 1979. Habib Hamzah was enthralled by the heroic story of Imam Khomeini and encountered new sources of knowledge from the intellectual thinkers of Iranian Shia Islam (such as Ali Syariati, Syahid Muthahari, and Allamah Thabathaba'i), which encouraged him to become a Shia follower. ${ }^{16}$ These facts affirm that the Shia identity in Indonesia was established in the New Order era, particularly following the 1979 Iranian revolution. ${ }^{17}$

The development of Shia communities in Bondowoso may also be observed from the founding of religious organizations, such as IJABI, in 2006, which is directly connected to the central IJABI led by Jalaluddin Rahmat established on July $11^{\text {st }}, 2000 . .^{18}$ In addition, the Shia community in

${ }^{14}$ Abdul Qodir Umar Mauladdawilah 17 Habaib Berpengaruh di Indonesia, Malang: Bayan $\&$ Pustaka Basma, 2010, 87-100.

${ }^{15}$ L.W.C.V.D Berg, Hadramaut dan Koloni Arab di Nusantara, Jakarta: INIS, 1989, 68-70.

${ }^{16}$ Interviews with Habib Umar, 8 September 2017 and Matkur, 6 November 2017.

${ }^{17}$ Martin van Bruinessen, "Genealogies of Islamic Radicalism in post-Suharto Indonesia", South East Asia Research, Vol. 10, No. 2 (2002), 117-154; Azyumardi Azra, "Islamic Thought: Theory, Concept, and Doctrines in the Context of Southeast Asian Islam", in K.S. Nathan \& Muhammad Hashim Kamali (eds.), Islam in Southeast Asia: Political, Social and Strategic Challenges for the $21^{\text {st }}$ Century, Singapore: ISEAS, 2005, 8-9; Masdar Hilmy, "The Political Economy"..., 27-57; Chiara Formichi, "From Fluit Identities"..., 101-126; Al-Makin, "Homogenizing Indonesian Islam"...., 1-31.

${ }^{18}$ Hilman Latief, "The Identity of Shi'a Sympathizers in Contemporary Indonesia”, Journal 
Bondowoso has Majlis Ta'lim As-Shadiq, established in 1995. The founder and chairman of both organizations were Habib Hamzah. After Habib Hamzah passed away, the leadership of the two Shia organizations passed to his successors, Habib Baqir for IJABI and Habib Abu Thalib bin Habib Hamzah for As-Shadiq, until now. However, the existence of those religious institutions is not only a symbol of that of the Shia community, but also an effective instrument for the development of Shia Islam in Bondowoso. ${ }^{19}$

\section{Rising anti-Shia mass mobilization in 2016}

With the growth of the Shia community in Bondowoso, an escalation of tension with Sunni groups was inevitable. The Sunni community, concerned about Shia growth, brought a number of complaints and, in their own religious preaching, started to cause alarm among Muslims by preaching of the heresy and danger of Shia teaching. In addition, they spread anti-Shia propaganda among the Muslims in Bondowoso, in which they would use MUI's fatwa to legitimize their views of the heresy of Shia religious teachings and views. As is commonly known, MUI is a faction of Islamic orthodoxy that often issues fatwa on the heresy, deviance, and danger of Shia Islam to the majority Sunni. ${ }^{20}$

The anti-Shia sentiment found momentum in a number of events, such as, firstly, the disruption by a crowd suspected to be from the Sunni community at the inauguration of IJABI's regional administration on 4 June 2006. Secondly, an incident where a student of Pesantren Al-Wafa in

of Indonesian Islam, Vol. 2, No. 2 (2008), 300-355; Chiara Formichi, "From Fluit Identities"..., 101-126; Moh Hasim, "Syi'ah: Sejarah Timbul”..., 147-158.

${ }^{19}$ Interviews with Syaeful Bahar, 25 November 2017 and Saehan, 15 October 2017.

${ }^{20}$ Mohammad Atho Mudzhar, Fatwa-Fatwa Majelis Ulama Indonesia: Sebuah Studi Pemikiran Hukum Islam di Indonesia 1975-1988, Jakarta: INIS, 1993, 114-126; Nur Ichwan, "The Local Politics of Orthodoxy The Majlis Ulama Indonesia in the Post-New Order Banten”, Journal of Indonesian Islam, Vol. 06, No. 1 (2012), 166-194; Dicky Sofjan, "Minoritization \& Criminalization of Shia Islam in Indonesia”, Journal of South Asian and Middle Eastern StudiesVol. XXXIX, No. 2 (2016), 29-44. 
Jambesari who identified as a follower of Shia was attacked and beaten on 12 August 2006. Thirdly, a mass action that attempted to burn the house of a Shia figure in Jambesari, kyai Mushawir, on 12 September 2006. Fourthly, the disruption of IJABI's haul and teaching events in Jambesari on 23-24 December 2006. In general, such acts of violence against Shia groups are localized and prevented from igniting the sentiment of Muslims in Bondowoso. ${ }^{21}$

The increasing anti-Shia sentiment in Bondowoso cannot, however, be separated from the tidal wave of radicalism at various levels, nationally and globally. In the context of the Indonesian democratic era, the opportunities for openness and freedom may be utilized by conservative and radical groups to promote their existence and religious teachings. Such minority groups are known to be vocal and militant in the conduct of their religion. In their representation of Islamic politics, the religious actions they perform often involve physical and symbolic instruments of violence. Their main agenda is the politicization of religion either for political or ideological interests, or both. ${ }^{22}$

In Bondowoso, the rise of conservatism is driven by conservative and radical Sunni groups. The FPI, Tarbiyah Movement, or PKS activists, Wahabism/Salafism among the followers of Al-Irsyad, HTI, and Islamic groups classified as Islamic hard-liners have emerged as the new leaders of violence against religious minorities. Unfortunately, the existence of these new Islamic groups contributes substantially to the increase of religious intolerance, discrimination, and violence against heterodox minority

\footnotetext{
${ }^{21}$ Imam Syaukani, "Konflik Sunni-Syi'ah di Bondowoso", Harmoni Jurnal MultikulturalMultireligius, Vol. VIII, No. 31 (2009), 85-87; Fauziah, "Potret Kerukunan Hidup”..., 647-661; Interview with, K.H. Abd Qodir Syams, 18 November 2017.

${ }^{22}$ Martin van Bruinessen (ed.), Contemporary Developments in Indonesian Islam: Explaining the Conservative Turn, Singapore: ISEAS, 2013; Robert W. Hefner, "Global Violence and Indonesian Muslim Politic”, American Anthropologist, Vol. 104, No. 3 (2002), 754-765; Masdar Hilmy, Islamism and Democracy in Indonesia Piety and Pragmatism, Singapore: ISEAS, 2010.
} 
groups, including the Shia. ${ }^{23}$ Since the emergence of these new variations of Islam, anti-Shia sectarian voices, and hatred and propaganda in Bondowoso have come from all directions. The anti-Shia voices crystallized into a collective action known as the anti-Milad Fatimah mass mobilization of 4-6 April 2016. The Milad Fatimah is an annual ritual routinely organized by the Shia group and there is usually very little tension with any Sunni groups. Large-scale opposition occurs when the IJABI invites national figures such as Jalaluddin Rakhmat and Haidar Bagir to the Milad Fatimah. ${ }^{24}$

Unlike previous cases, the rejection of Milad Fatimah in 2016 involved approximately 3,500 people from various Islamic groups. This mass mobilization was also reported by the national and local press, in print and online media, leading to a potential clash between anti-Milad Fatimah groups and the Shia minority group unless the government ensured safety by mobilizing a large number of security officers. Since the anti-Shia groups could not force the regency administration to cancel the Milad Fatimah, they organized another event to compete with it, with the theme of grand preaching and praying together, at Mosque At-Taqwa. ${ }^{25}$

In a series of mass actions, the anti-Milad Fatimah made various claims against the Shia, such as heresy and danger of Shia teaching for Islamic Sunni teaching as followed by most of Indonesia's Muslims; mut'ah marriage; and directing insults toward the sahabat (companions) of Prophet Muhammad. In addition, they linked the alleged dangers posed by the Shia to issues of nationality, claiming on the banners and posters they brought to the demonstration that the existence of Shia in Indonesia is a factor to split the people, a real threat to the unity of the nation or

\footnotetext{
${ }^{23}$ Endang Turmudi dan Riza Sihbudi (ed.), Islam dan Radikalisme”..., 2005; Abdurrahman Wahid (ed.), Ilusi Negara Islam..., 2009; Nur Ichwan, "The Local Politic of Orthodoxy"..., 166-194.

${ }^{24}$ Interviews with Matkur, 6 November 2017; Syaeful Bahar, 25 November 2017; Habib Baqir, 25 November 2017; Habib Murtadlo, 25 November 2017; http://bangsaonline.com.

${ }^{25}$ http://faktasyiah.blogspot.co.id; http://m.okezone.com.
} 
NKRI and national disintegration. The crowd, therefore, insisted that the government cancel the permit for the Milad Fatimah, as in their opinion, giving permission for such an event was equal to legitimatizing the Shia community, with their heretical teachings. ${ }^{26}$

Classic, religious sectarian issues are evidently useful to ignite emotions between groups of Muslims in order to encourage action, and such issue framing is reminiscent of the success of Islam defending action in Jakarta. Both actions exploited religious sentiment to mobilize crowds in order to achieve political goals. A crowd of 3,500 people is large enough to be effective in a regency. The anti-Milad Fatimah demonstrations were is recorded as the largest Islamic demonstration against the Shia in Bondowoso. It was also through this action that an alliance between Islamic conservative and radical groups was realized, as they found themselves united, in one religious coalition, by anti-Shia sentiment. ${ }^{27}$

\section{Alliances among the Godly Muslim}

The anti-Milad Fatimah collective action did not only involve a large number of people from a range of socio-religious backgrounds, but also an alliance between groups known as, to borrow the term used by Jeremy Menchik, 'Godly Muslims'. ${ }^{28}$ They consist of conservative nahdliyin, the radical FPI, Al-Irsyad Wahabi/Salafi, PKS activists, and HTI elements. Unlike the Islam Defending Action 212, which places the FPI as the main spokesman, the action to oppose the Milad Fatimah was pioneered by conservative nahdliyin elites. Among the central figures was K.H. Mohammad Hasan Abdul Muiz, son of K.H. Abdul Muiz Tirmidzi, the caretaker of pondok pesantren (Islamic Boarding School) Sayyid Muhammad Alawi al-Maliki, Koncer, Bondowoso.

\footnotetext{
${ }^{26}$ Interviews with Mudassir, 24 November 2017 and K.H. Hasan, 30 September 2017.

${ }^{27}$ Nur Ichwan, "The Local Politic of Orthodoxy"..., 166-194. Al-Makin, "Homogenizing Indonesian Islam”..., 1-31.

${ }^{28}$ Jeremy Menchik, "Productive Intolerance: Godly Nationalism in Indonesia", Comparative Studies in Society and History, Vol. 56, No. 3 (2014), 591-621.
} 
During his time in office as the chairman of MUI Bondowoso, kyai Abdul Muiz was known as the most vocal figure in safeguarding MUI's fatwa related to Shia's heresy and, to this end, frequently supported anti-Shia actions and legitimized them as Aswaja, defending actions against Shia's desecrating and heretical teaching. ${ }^{29}$

When kyai Abdul Muiz al-Tirmidzi died, such anti-Shia actions were continued by his son, kyai Muhammad Hasan Muiz, who is, like his father, known to be vocal in expressing anti-Shia sentiment and propaganda. When the Shia people planned to hold a high-profile event, Milad Fatimah, and invited Shia national figures, he expressly opposed it. Together with the other conservative Sunni figures, he established a forum called FOKUS (Sunni Ulama Communication Forum), which combined the forces of ulama (religious scholars), kyai (religious people, mostly from pesantren) and pesantren alumni networks existing in the Bondowoso Regency. The alumni networks that joined FOKUS included IKSASS (Salafiyyah Syafiiyyah Situbondo Students and Alumni Association), IAS (Sidogiri Islamic Boarding School Alumni Association), TANAZZAHA (Zainul Hasan Islamic Boarding School Alumni Association), IKAPETE (Tebu Ireng Islamic Boarding School Alumni Association), Sarang Islamic Boarding School Alumni Association (Central Java), and Al-Azhar Egypt Alumni Association, and through this forum students and Muslims were mobilized to join together and oppose the Milad Fatimah. ${ }^{30}$

The conservative NU youths took similar initiatives, forming their own movement called GERPAS (Anti-Shia Youth Movement). This organization was pioneered by a young kyai, currently an alumnus of pesantren Sidogiri, an increasingly prominent, kyai Mudassir, who was inspired by the Muslim national figures' ijtihad in forming the Anti-Shia

\footnotetext{
${ }^{29}$ Interviews with K.H. Abd. Qodir Syams, 18 November 2017; Syaeful Bahar, 25 November 2017; and Matkur, 6 November 2017.

${ }^{30}$ Interviews with kyai Mudassir, 24 November 2017 and K.H. Hasan, 30 September 2017.
} 
National Alliance (ANNAS) in response to the Sampang Sunni-Shia conflict in 2011. ${ }^{31}$ Through GERPAS, he actively organizes the millennial generation of Muslims to join in and become involved in Aswaja defense actions to oppose Milad Fatimah. ${ }^{32}$

In practice, both anti-Shia mainstream organizations, FOKUS and GERPAS, are the main drivers of anti-Milad Fatimah actions. The proponents of these movements are aware that any social movement needs the support of other groups to be successful in applying strong pressure externally. They, therefore, acquire allies by establishing alliances with other groups including Muslim elites from the FPI, conservative Islamic boarding school elites, Wahabi/Salafi groups from the Al-Irsyad organization branch, PKS activists, and HTI. This Islamic inter-group alliance successfully forced the administration of the Bondowoso regency and East Java province to respond seriously to its mass protests by sending approximately 1,700 security officers. ${ }^{33}$

However, the establishment of coalitions between conservative and radical Sunni groups cannot be separated from their political interests in not only opposing the commemorations but also de-legitimizing Shia groups. As is generally true of anti-Shia movements, those involved in the anti-Milad Fatimah mass mobilization have a relatively uniform perspective that Shia is a heretic, deviant religious teaching which is a threat to Sunni teaching. ${ }^{34}$

The conservative and radical groups label Shia as an extreme enemy of Islam against which it is justified to fight using violence. They believe that the removal of the enemy of Islam will maintain the authenticity of Islamic teaching. According to them, Islam has become disordered as

\footnotetext{
${ }^{31}$ Dede Syarif, Iskandar Zulkarnain, Dicky Sofjan, "Anti-Shi' ism in Indonesia: Geneology, Development, and Methods", Harmoni: Jurnal Multikultural $\mathcal{E}$ Multireligius, Vol. 16, No.1 (2017), 24-37.

${ }^{32}$ Interview with Mudassir and FGD, 25 September \& 15 October 2017.

${ }^{33}$ FGD, 15 October 2017; http://www.timesindonesia.co.id.

${ }^{34}$ Dicky Sofjan, "Minoritization \& Criminalization”..., 29-44.
} 
a result of Muslim leaders' indecision about how to respond to Islam's enemy, and they, therefore, criticize any tolerant and accommodative attitudes of Muslim groups, whom they label as 'liberal' protectors of the enemy of Islam. ${ }^{35}$

\section{Islamizing public space}

The involvement of Islamic radical groups in mass mobilization indicates that there is a political agenda broader than merely demanding the cancellation of Milad Fatimah. FPI, Tarbiyah/PKS activists, HTI, and AlIrsyad Wahabi/Salafi are Islamic radical groups whose religious movements are more politically-oriented than religious. Although they have different approaches and strategies, they are similar in how they apply Islamic sharia and Islamize power and the public space. ${ }^{36}$

In practice, the radical HTI activists and Wahabi/Salafi choose a revolutionary approach to encourage socio-political change, while PKS activists tend to choose moderate-accommodative approaches within a democratic system. ${ }^{37}$ In short, we may say that the involvement of those Islamic political agents in the mass mobilization action is not merely related to the objective-manifest agenda of rejecting Milad Fatimah or delegitimizing Shia as a means to affirm Indonesian Islamic orthodoxy, ${ }^{38}$ but is far bigger and political than all of them, which is aim to Islamize the institutions of power. They offer sharia as an alternative to the national principle and

\footnotetext{
${ }^{35}$ Interviews with Kyai Mudassir, 24 November 2017; K.H. Hasan, 30 September and Supriyadi, 2 December 2017.

${ }^{36}$ Endang Turmudi dan Riza Sihbudi (ed.), "Islam dan Radikalisme”..., 2005, 164; Abdurrahman Wahid (ed.), "Ilusi Negara Islam”..., 2009, 164; Martin van Bruinessen (ed.), "Contemporary Developments"..., 35-39; M. Imdadun Rahmat, Ideologi Politik PKS, Dari Masjid Kampus ke Gedung Parlemen, Yogyakarta: LKiS, 2008, 114.

${ }^{37}$ Masdar Hilmy, "Islamism and Democracy", 117-126; Masdar Hilmy, "Radikalisme Agama dan Politik Demokrasi di Indonesia Pasca Orde Baru”, Jurnal MIQAT, Vol. XXXIX, No. 2 (2015), 407-425.

${ }^{38} \mathrm{Al}-\mathrm{Makin}$, "Homogenizing Indonesian Islam”...,1-31.
} 
emphasize its advantages over any other system, including secularism. ${ }^{39}$

The indication of a hidden political agenda is expressed by moderate nahdliyin intellectuals, activists, and figures as, to borrow the conservative group's term, liberal. According to them, the fact that HTI joins the antiMilad Fatimah mass action cannot only be textually read as their solidarity in affirming Islamic orthodoxy. More than that, their involvement cannot be separated from their mainstream political agenda, which is to replace the power system. ${ }^{40}$ In this case, they used the momentum of anti-Milad Fatimah mass protests to show their identity, existence and classical, political agenda, the affirmation of khilafah (caliphate). In their political doctrine, khilafah is the only means for Muslims to gain freedom from subjugation by the unfaithful and to live as directed by God. ${ }^{41}$

HTI activists' involvement in the anti-Milad Fatimah mass mobilization was considered by the liberal-moderate nahdliyin group as a form of the carelessness of the conservative nahdliyin group which became the main promoter of the mobilization. In fact, the mass mobilization was used well by HTI activists to show their group identity and political agenda. The flag attributes and various properties of action written "la ilaaha illallahu muhammadur rasulullah" on sheets of black fabric were truly put on display in the anti-Milad Fatimah mass protests, and the presence of HTI in the mass action was far more dominant than that of the other participants. To critics of the moderate-liberal groups, the thousands of nahdliyin in the crowds represented only a 'Trojan Horse' for the Islamic political groups,

\footnotetext{
${ }^{39}$ Lily Zubaidah Rahim, "The Road Less Travelled: Islamic Militancy in Southeast Asia”, Critical Asian Studies, Vol. 32, No. 2 (2003), 209-232; Noorhaidi Hasan, Laskar Jihad: Islam, Militansi dan Pencarian identitas di Indonesia Pasca Orde Baru, Jakarta: LP3ES dan KITLV, 2008, 17; Greg Fealy, "Bukan Sekedar Ahok: Menjelaskan Aksi Massa pada 2 Desember", in Indonesia At Melbourne, Melbourne University, 12 December, 2016.

${ }^{40}$ Interview with Syaeful Bahar, 25 November 2017; Mas'ud, 17 October 2017; and FGD, 25 September \& 15 October 2017.

${ }^{41}$ Greg Fealy, "Islamic Radicalism in Indonesia, The Faltering Revival?", Southeast Asian Affairs (2004), 104-121; Masdar Hilmy, Islamism and Democracy..., 2010, 117-122.
} 
particularly HTI, with their political agenda to affirm khilafah Islamiyah. ${ }^{42}$

Similarly, PKS's involvement was regarded as an impure or untrue action aimed at canceling the commemoration organized by the Shia group. It is a public secret that their religious activities are closely related to the Islamization agenda. Unlike the HTI that rejects the path of democracy, they are relatively accommodative to the democratic system in realizing their political agenda, which they do through the political party they have established, PKS. Besides formal politics, they also use socio-religious paths such as da'wah activities, including halaqah, dawrah, pengajian (religious lectures), liqa' (meetings), rihlah (tours), mabit (overnight stays), seminars, workshops, and formal educational institutions such as establishing various Islamic integrated schools. ${ }^{43}$ They use these two paths as their principal means of realizing their Islamization agenda which, in accordance with Hasan Banna's doctrine, starts from individual to family, community, and nation, and finally the world. ${ }^{44}$

The Islamization agenda can also be seen in the involvement of other Islamic radical Wahabi/Salafi figures. Salafi figures from the Al-Irsyad organization branch and the leader of the Al-Ishlah Islamic boarding school are suspected to express the Islamization of power. In various popular Islamization actions on a national level, such as the ' 212 action', they are the principal figures fully involved in the mass mobilization. Ideologically, they have ideals uniform with most of the ' 212 action' leaders. The Jakarta Sharia Concept, for example, is adopted as an alternative to Islamization in

\footnotetext{
${ }^{42}$ Interviews with Mas'ud, 17 October 2017 and Matkur, 6 November 2017.

${ }^{43}$ Noorhaidi Hasan, "Islamizing Formal Education"..., 1-29; Noorhaidi Hasan, "Islamist Party, Electoral Politics and Da'wah Mobilization among Youth, The Prosperous Justice Party (PKS) in Indonesia”, Journal of Indonesian Islam, Vol. 06, No. 01 (2012), 17-47.

${ }^{44}$ Bassam Tibi, Islam dan Islamisme, Bandung: Mizan, 2012, 53-55; Suadi Asy'ari, "Incorporating Islamism into Secular Education System, An Attempt of Gradual Islamization of the State and Society by an Indonesian Tarbiyah Movement in Jambi", Journal of Indonesian Islam, Vol. 11, No. 1 (2017), 29-58. Nazih Ayubi, Political Islam: Religion and Politics in the Arab World, London: Routledge, 2004, 123.
} 
Bondowoso. They have a great interest in making Bondowoso an Islamic regency and therefore participate in any attempts toward the realization of regional sharia regulation..$^{45}$ Any attempts of the anti-Shia groups to push the regional sharia regulation agenda indicate that the movement for the formalization of Indonesian Islamic law remains active. ${ }^{46}$

\section{Challenging religious authority and local power}

Behind the collective agenda to reject the Milad Fatimah, there are other more pragmatic interests. A competitive atmosphere of fighting for religious authority is palpable in the mass action and in the disputes among different minority groups as well as between minority and majority groups. Just like the Shia, the conservative and radical Islamic groups are also minorities compared to the moderate Muslim majority. Moreover, there are disputes and ideological confrontations between those involved in the alliance. Disputes between conservative nahdliyin groups and Wahabi/Salafi groups, for example, are a commonplace practice in religious life in Bondowoso. Each group is competing to fight for and control Islamic public space. ${ }^{47}$

The conservative and radical minority groups that are mutually derived from Sunni ${ }^{48}$ attempted to abate their differences and cooperated to oppose the Milad Fatimah. It is, however, beyond doubt that their intention to remove Shia is not merely rooted in ideological motives-specifically the Sunni theological doctrine that Shia is a heretical religious teaching. ${ }^{49}$ More

\footnotetext{
${ }^{45}$ Interviews with some teachers of Al-Ishlah Islamic boarding school, 14 September 2017 and Faisol Nasr bin Madi, 8 September 2017.

${ }^{46}$ Jeremy Menchik, "Productive Intolerance"..., 591-621.

${ }^{47}$ Muhammad Ansor, "Post-Islamism and the Remaking of Islamic Public Sphere in PostReform Indonesia", Studia Islamika, Vol. 23, No. 3 (2016), 471-515; Al-Makin, "Homogenizing Indonesian Islam"...,1-31; FGD, 25 September \& 15 October 2017.

${ }^{48}$ Azyumardi Azra, "The Ahl al-Sunnah wa al-Jama'ah in Southeast Asia: The Liteature of Malay-Indonesia 'Ulama' and Reforms”, Heritage of Nusantara International Journal of Religious Literature and Heritage, Vol. 2, No. 1 (2013), 1-21.

${ }^{49}$ Dicky Sofjan, "Minoritization \& Criminalization”..., 29-44; Ken Miichi, "Minority Shi'a”..., 2016; Al-Makin, "Homogenizing Indonesian Islam”..., 1-31.
} 
than that, their involvement in the action cannot be separated from the political motive to fight for authority among Muslim minority groups. It should be noted that Shia is a minority which has grown relatively strongly compared to Sunni minority groups. They also consider that Shia's growth may seriously threaten Sunni religious authority. ${ }^{50}$

Moreover, the contest for authority also illustrates a conflicting relationship between the Shia minority group and the Sunni majority group. Sunni conservative and radical groups exist in Bondowoso in numbers far below those of moderate Muslims. In the case of the Shia, for example, it was the moderate Muslim group that shaped the regency administration's inclusive policy to give permission for the Milad Fatimah to take place. This condition is in contrast to other regions facing the same situation, such as Sampang (Madura) where conservative and radical groups have a dominant influence over the government's discriminatory policy-making. ${ }^{51}$

The competition for authority between the conservative and radical groups on the one side and the moderate group on the other crosses the domination of both groups in religious institutional control locally. For example, conservative nahdliyin's hatred of what they call 'Said Aqiel Siradj's nahdliyin', may be read as a form of authority and power contest in dominating the Nahdlatul Ulama Branch Administrator (Pengurus Cabang Nahdlatul Ulama - PCNU) Bondowoso organization. The mass action they promoted to oppose the Fatimah Birth commemoration clearly indicates their opposition to the power of PCNU Bondowoso, which is dominated

${ }^{50}$ Interview with Kyai Mudassir, 24 November 2017; K.H. Hasan, 30 September 2017; and K.H. Abd Qodir Syams, 18 November 2017.

${ }^{51}$ Khoirul Mustamir, "Agama Menegara: Potret Pembajakan Kekuasaan Negara dan Masa Depan Syi'ah di Jawa Timur”, Ma'arif, Vol. 10, No. 2 (2015), 268-296; A'an Suryana, "Discrepancy in State Practices The Case of Violence against Ahmadiyah and Shi' a Minority Communities during the Presidency of Susilo Bambang Yudoyono", Al-Jami'ah, Vol. 5, No. 1 (2017), 71-103. 
by the moderate-liberal group. The term 'NU garis lurus' (NU straight line) or 'NU kanan' (NU right wing) used by the moderate nahdliyin group to describe the conservative group, and the term 'NU Said Aqiel Siradj' with its liberal and pro-Shia connotations used by the conservative nahdliyin group about the moderate group, is clear evidence of internal competition within the nahdliyin in fighting for authority and Islamic institutions. ${ }^{52}$

Besides its domination of NU organization, the moderate-liberal nahdliyin group also has a strong influence on the regime of the regency administration and wider access to many semi-governmental religious institutions and other governmental institutions. MUI, Forum for Religious Harmony (FKUB), Education Council, and Local Research Council are some of the institutions under the control of moderate nahdliyin figures. MUI, which is always under the control of the conservative group, is, in the case of Bondowoso, controlled by the moderate-liberal group. Therefore, the local MUI did not fully perform its function to support the conservative and radical groups in influencing the government's policy to suspend the event. Instead of displaying conservative behavior, MUI Bondowoso, particularly in the last two periods, has progressively rejected any fatwa on Shia heresy issued by central MUI or provincial MUI ${ }^{53}$ and, as a result, has been accused of being a heretic and liberal by Muslim conservative and radical groups. ${ }^{54}$

\section{Conclusion}

This paper has demonstrated that the 2016 anti-Milad Fatimah mass mobilization in Bondowoso had a strong ideological and socio-political interest. The anti-Milad Fatimah movement can be seen as the means by

\footnotetext{
${ }^{52}$ FGD, 25 September \& 15 October 2017.

${ }^{53}$ http://muijatim.org.

${ }^{54}$ Interviews with Kyai Mudassir, 24 November 2017; K.H. Hasan, 30 September; K.H. Abd. Qodir Syams, 18 November 2017.
} 
which the militant-radical Sunni elites attempted to undermine religious authority in the Islamic public sphere and also local power resources. The conservative nahdliyin, FPI, Tarbiyah or PKS activists, HTI, and Wahabi/Salafi wings in Al-Irsyad are the Sunni militant-radical groups, which became the main anti-Milad Fatimah figures allied to exclude Shia communities from the public sphere. Through FOKUS and GERPAS, they organized Muslims not only to force the cancellation of the Milad Fatima event but also to delegitimize the Shia group from the public sphere in Bondowoso. Their main interest in doing so was not only related to Indonesian Islamic orthodoxy affirmation projects, but also to ideological and political interests. However, the involvement of HTI, PKS activists, and Wahabi/Salafi of Al-Irsyad in the anti-Milad Fatimah protests showed that there was a strong ideological-political agenda such as Islamization.

Meanwhile, the socio-political agenda behind the anti-Milad Fatimah mass mobilization can be seen in the competition, particularly between Islamic conservative groups and Islamic moderate groups, over local power resources. This paper also has found that the target of the anti-Milad Fatimah is not only Shia community, but also the government and the Islamic moderate groups. In various cases of Sunni-Shia conflict in Bondowoso, the government and moderate Muslims always show inclusivity to the minority labeled as deviant. In addition, moderate Muslims have dominant access to various local power resources. Their closeness to local government gives them substantial opportunities to access various power resources such as the Local House of People's Representatives, Local Research Council, etc. It is in this context that the rising anti-Milad Fatimah mass mobilization cannot be separated from competition for control of religious institutions and systems of State power at the local level. 


\section{Bibliography}

Akmaliah, Wahyudi, "Kekerasan dan Pengusiran Atas Nama Agama Pasca Rejim Orde Baru: Studi Kasus Konflik Syi'ah Sampang”, Maarif: Arus Pemikiran Islam dan Sosial, Volume 10, Number 2 (2015): 221-242.

Al-Amin, Ainur Rofiq. Membongkar Proyek Khilafah Ala Hizbut Tahrir di Indonesia. Yogyakarta: LKiS, 2012.

Ansor, Muhammad, "Post-Islamism and the Remaking of Islamic Public Sphere in Post-Reform Indonesia”, Studia Islamika, Volume 23, Number 3 (2016): 471-515.

Asy'ari, Suadi, "Incorporating Islamism into Secular Education System, An Attemp of Gradual Islamization of the State and Society by an Indonesian Tarbiyah Movement in Jambi”, Journal of Indonesian Islam, Volume 11, Number 1 (2017): 29-58.

Ayubi, Nazih. Political Islam: Religion and Politics in the Arab World. London: Routledge, 2004.

Azra, Azyumardi, "Islamic Thought: Theory, Concept, and Doctrines in the Context of Southeast Asian Islam", in K.S. Nathan \& Muhammad Hashim Kamali (eds.), Islam in Southeast Asia: Political, Social and Strategic Challenges for the $21^{\text {st }}$ Century. Singapore: ISEAS, 2005.

Azra, Azyumardi, "The Ahl al-Sunnah wa al-Jama'ah in Southeast Asia: The Liteature of Malay-Indonesia 'Ulama' and Reforms”, Heritage of Nusantara International Journal of Religious Literature and Heritage, Volume 2, Number 1 (2013): 1-21.

Bruinessen, Martin van, "Genealogies of Islamic Radicalism in post-Suharto Indonesia", South East Asia Research, Vol. 10, No. 2 (2002), 117-154

Bruinessen, Martin van (ed.). Contemporary Developments in Indonesian Islam: Explaining the Conservative Turn. Singapore: ISEAS, 2013.

Dijk, Kees van, and Kaptein, Nico J.G. (ed.). Islam, Politics and Change, the Indonesian Experience after the Fall of Suharto. Leiden: Leiden University Press, 2016.

Fauziah, "Potret Kerukunan Hidup Umat Beragama di Kabupaten Bondowoso, Jawa Timur", Harmoni Jurnal Multikultural $\mathfrak{E}$ Multireligius, Volume X, Number 3 (2011): 647-661.

Fealy, Greg, "Bukan Sekedar Ahok: Menjelaskan Aksi Massa pada 2 Desember", Indonesia At Melbourne, Melbourne University, 12 Desember, 2016.

Fealy, Greg, "Islamic Radicalism in Indonesia, The Faltering Revival?", Shoutheast Asean Affairs (2004): 104-121. 
Formichi, Chiara, "From Fluid Identities to Sectarian Labels, a Historical Investigation of Indonesia's Shi' i Communities", Al-Jami'ah: Journal of Islamic Studies, Volume 52, Number 1 (2014):101-126.

Hasan, Noorhaidi. Laskar Jihad: Islam, Militansi dan Pencarian identitas di Indonesia Pasca Orde Baru. Jakarta: LP3ES dan KITLV, 2008.

Hasan, Noorhaidi. Islamizing Formal Education: Integrated Islamic School and New Trend in Formal Education Institution in Indonesia. Singapore: S. Rajaratnam School of International Studies, 2009.

Hasan, Noorhaidi, "Islamist Party, Electoral Politics and Da'wah Mobilization among Youth, The Prosperous Justice Party (PKS) in Indonesia", Journal of Indonesian Islam, Volume 06, Number 01 (2012):17-47.

Hasim, Moh, "Syi'ah: Sejarah Timbul dan Perkembangannya di Indonesia", Jurnal Analisa, Volume 19, Number 02, (December 2012):147-158.

Hefner, Robert W, "Religious Resurgence in Contemporary Asia: Southeast Asian Perspectives on Capitalism, State, and the New Piety", The Journal of Asian Studies, Volume 69, Number 4 (2010): 131-47.

Hefner, Robert W, "Global violence and Indonesian Muslim Politic", American Anthropologist, Volume 104, Number 3 (2002):754-765.

Hilmy, Masdar, "Radikalisme Agama dan Politik Demokrasi di Indonesia Pasca Orde Baru”, Jurnal MIQAT, Volume XXXIX, Number 2 (2015): 407-425.

Hilmy, Masdar, "The Political Economy Sunni-Shi'ah Conflict in Sampang Madura", Al-Jami'ah: Journal of Islamic Studies, Volume 53, Number 1 (2015): 27-51.

Hilmy, Masdar. Islamism and Democracy in Indonesia Piety and Pragmatism. Singapore: ISEAS, 2010.

Hilmy, Masdar, "The Politics of Realitation: The Backlash of Radical Islamists to Deradicalization Project in Indonesia", Al-Jami'ah, Volume 51, Number 1 (2013): 129-158.

Ichwan, Nur, "The Local Politics of Orthodoxy The Majlis Ulama Indonesia in the Post-New Order Banten", Journal of Indonesian Islam, Volume 06, Number 01 (2012): 166-194.

Ichwan, Nur, MUI, "Gerakan Islamis, dan Ummat Mengambang", Maarif, Volume II, Number 2 (2016): 87-104.

Latief, Hilman, "The Identity of Shi'a Symphatizer in Contemporary Indonesia", Journal of Indonesian Islam, Volume 2, Number 2 (2008): 300-355.

Makin, Al, "Homogenizing Indonesian Islam: Persecution of the Shia Group in Yogyakarta”, Studia Islamika, Volume 24, Number 1 (2017): 1-31. 
Menchik, Jeremy, "Productive Intolerance: Godly Nationalism in Indonesia", Comparative Studies in Society and History, Volume 56, Number 3 (2014): 591-621.

Mauladdawilah, Abdul Qodir Umar. 17 Habaib Berpengaruh di Indonesia, Malang: Bayan \& Pustaka Basma, 2010.

Miichi, Ken. Minority Shi'a Groups as a Part of Civil Society in Indonesia, 2016. http://www.mei.edu/content/map/minority-shi-groups-civil-societyindonesia?print $=$

Mudzhar, Mohammad Atho. Fatwa-Fatwa Majelis Ulama Indonesia: Sebuah Studi Pemikiran Hukum Islam di Indonesia 1975-1988. Jakarta: INIS, 1993.

Mustamir, Khoirul, "Agama Menegara: Potret Pembajakan Kekuasaan Negara dan Masa Depan Syi'ah di Jawa Timur", Ma'arif, Volume 10, Number 2 (2015): 268-296.

Rahim, Lily Zubaidah, "The Road Less Travelled: Islamic Militancy in Southeast Asia”, Critical Asian Studies, Volume 32, Number 2 (2003): 209-232.

Rahmat, M. Imdadun. Ideologi Politik PKS, Dari Masjid Kampus ke Gedung Parlemen. Yogyakarta: LKiS, 2008.

Rijal, Syamsul, "Internal Dynamics within Hadrami Arabs in Indonesia From Social Hierarchy to Islamic Doctrins", Journal of Indonesian Islam, Volume 11, Number 1 (2017):1-28.

Setara Institute. Negara Harus Bersikap: Tiga Tahun Laporan Kondisi Kebebasan Beragama/Berkeyakinan di Indonesia. Jakarta: Setara Institute, 2010.

Sofjan, Dicky, "Minoritization \& Criminalization of Shia Islam in Indonesia", Journal of South Asian and Middle Eastern Studies, Volume XXXIX, Number 2 (2016): 29-44.

Suryana, A'an, "Discrepancy in State Practices The Case of Violence against Ahmadiyah and Shi'a Minority Communities during the Presidency of Susilo Bambang Yudoyono", Al-Jami'ah, Volume 5, Number 1 (2017): 71-103. Syaukani, Imam, "Konflik Sunni-Syi'ah di Bondowoso", Harmoni Jurnal Multikultural-Multireligius, Volume VIII, Number 31 (2009): 85-87.

Syarif, Dede, Zulkarnain, Iskandar, Sofjan, Dicky, "Anti-Shi'ism in Indonesia: Geneology, Development, and Methods", Harmoni: Jurnal Multikultural $\mathcal{E}$ Multireligius, Volume 16, Number 1 (2017): 24-37.

Tibi, Bassam. Islam dan Islamisme. Bandung: Mizan, 2012.

Turmudi, Endang \& Riza Sihbudi (ed.). Islam dan Radikalisme di Indonesia. Jakarta: LIPI, 2005. 
IJIMS: Indonesian Journal of Islam and Muslim Societies, Volume 10, Number 1, June 2020: 25-48

Al-Qurtuby, Sumanto, "Arab and "Indo-Arabs" in Indonesia: Historical Dynamics, Social Relations and Contemporary Changes", International Journal of Asia Pasific Studies, Volume 13, Number 2 (2017): 45-72.

Wahid, Abdurrahman (ed.). Ilusi Negara Islam: Ekspansi Gerakan Islam Transnasional di Indonesia. Jakarta: Gerakan Bhinneka Tunggal Ika, the Wahid Institute dan Maarif Institute, 2009.

Wahid Institute. Laporan Kebebasan Beragama/Berkeyakinan dan Toleransi 2010. Jakarta: Wahid Institute, 2010.

Mass Media and Online:

Kompas.com, 05/01/2017.

http://muijatim.org

http://m.okezone.com

http://timesindonesia.co.id

http://www.wahidinstitute.org

http://faktasyiah.blogspot.co.id 